\title{
Challenges to Women Active Participation in Politics in Nigeria
}

\author{
Ugwuegede Patience Nwabunkeonye \\ Institute of Management and Technology, Enugu \\ *Corresponding Author: mizpye@yahoo.com
}

Copyright @ 2014 Horizon Research Publishing All rights reserved.

\begin{abstract}
Poor participation of women in politics and governance has been a major concern at global level. In Nigeria, women participation in politics is not proportionate to the $50 \%$ of the nation's population which they represent and has not translated into equal representation in political leadership positions. The global issue of goal 3 (to promote gender equality and empower women) of the Millennium Development Goals (MDGs) and other international clarion calls for bridging the gap created by long-term discriminations against women and making women visible in politics made Nigeria to recognize women in the political sphere, and include them in both appointive and elective positions. Yet, there persists poor participation of women in politics and the number of women in political positions in Nigeria is growing at a slow rate despite efforts to change such trend. Based on secondary sources of information, this paper, examined the challenges Nigerian women still face in active participation in politics such as discriminatory socio-cultural and religious practices; lack of finance; under-representation of women in governance; unhealthy political environment; political party discrimination; wrong perception of women in politics; lack of family, fellow women and media support; indigenization of women political aspirants; among others. This paper recommended measures to guarantee women active participation in politics in Nigeria such as review of discriminatory practices; economic empowerment; support from family, fellow women and media; equal representation in governance; healthy political environment; proper perception of women in politics, among others.
\end{abstract}

Keywords Politics, Women, Active Participation, Indigenization, Challenges

Theme: Gender and Women's Studies, Women and Politics

\section{Introduction}

Poor participation of women in politics and governance has been a major concern at global level. In Nigeria, women participation in politics is not proportionate to the $50 \%$ of the nation's population which they represent and has not translated into equal representation in political leadership positions. The global issue of goal 3 (to promote gender equality and empower women) of the Millennium Development Goals (MDGs) and other international clarion calls for bridging the gap created by long-term discriminations against women and making women visible in politics made Nigeria to recognize women in the political sphere, and include them in both appointive and elective positions. Yet, there persists poor participation of women in politics and the number of women in political positions in Nigeria is growing at a slow rate despite efforts to change such trend by Nigerian women groups/ advocates/activists, civil society organizations, Nigerian government and International agencies and to increase women active participation in both politics and public life. This situation persistently falls below the recommended $30 \%$ of the Beijing Platform of Action and 35\% recommendation of National Policy on Women in Nigeria.

Also, Nigerian women have the guaranteed rights to participate in active politics and governance by virtue of Section 42(1) of the 1999 Constitution of the Federal Republic of Nigeria which states that: "A citizen of Nigeria of a particular community, ethnic group, place of origin, sex, religion or political opinion shall not, by reason only that he is such a person be subjected to any form of discrimination. This further confirms that you can go to court to seek redress if as a woman your franchise is violated and that the constitution as a whole prohibits discrimination on the basis of sex".

However, over the years, there has been a remarkable increase in women participation when measured with certain standards like the number of women who vote in elections; the number of appointive and elective positions held by women; number of women related policies implemented by government; and so on.

Yet, there is observed extensive discrimination against women and under- representation of them in politics and governance in Nigeria when compared with their male counterparts in actual practice.

The statistics from table 1 revealed that from 1999-2011 general elections in Nigeria, no woman was elected into the 
office of the governor in any of the 36 states and that of the president of the federation. Moreover, out of 109 Senators, there were only 3 women $(2.8 \%)$ in 1999 ; which increased to $4(3.7 \%)$ in 2003; a further increase to $9(8.3 \%)$ in 2007 ; and a slight decline to 7 (6.4\%) in 2011. Also, out of 360 House of Representative members, there were only 12 women (3.3\%) in 1999; which increased to $21(5.8 \%)$ in 2003; a further increase to $25(6.9 \%)$ in 2007 ; and a slight increase to $26(7.2 \%)$ in 2011. In addition, out of 990 State House of Assembly members, there were only 24 women $(2.4 \%)$ in 1999; which increased to $40(3.9 \%)$ in 2003 ; a further increase to $57(5.8 \%), 68(6.9 \%)$ in 2007 and 2011 respectively. Furthermore, out of $829,881,887$, State House of Assembly Committee members, there were only 18 women (2.2\%), 32 (3.6\%), 52 (5.9), in 1999, 2003, and 2007 respectively with slight increases. But in 2011, there was no woman out the 887 State House of Assembly Committee members. Considering the office of the Local Government Area Chairperson, there were only 13 (1.8\%), 15 (1.9\%) and $27(3.6 \%)$ women in 1999, 2003 and 2007 respectively with slight increases. While in 2011, no woman was elected in to the office of Local Government Area chairperson. Finally, out of 6368 Councilors, they were only $69(1.1 \%)$ women which increased to $267(4.2 \%)$ in 2003 and reduced to 235 $(3.7 \%)$ in 2007 . While in 2011 , no woman was elected into the office of Councilors. Also, table 2 revealed that the number of women elected as deputy governors for 1999 , 2003, 2007, and 2011 were 1, 2, 6, and 1 respectively. The total number of Deputy Governors was 36 for 1999, 2003, 2007 and 2011. In 1999, according to Luka (2012), there was an improvement on women political participation with the appointment of 4 out of the 29 senior ministers representing $13.7 \%$ and 3 out of the 18 junior ministers representing $16.6 \%$; 2 women advisors and 2 senior special assistants and 6 special assistants and 1 special assistant to the vice president as well as 8 permanent secretaries. Women were also appointed as commissioners and therefore members of the executive councils in all the states (Kolawole, Abubakar, Owonibi, and Adebayo, 2012). Considering the 2011 political appointments, out of 7 principal officers of the Senate, there was no woman; there was only 1 woman $(10 \%)$ out of 9 officers of the House of Representative; and for the ministerial appointments as at $7^{\text {th }}$ August,2011, there 13 women $(32 \%)$ out of 41 . Tables1\&2 showed women representation in two arms of government only: Legislative arm ( Senate, House of Representatives, State House of Assembly and Councilors); Executive arm (President, Governor, Deputy Governor, Local Government Chairperson); including political appointees.

Table 1. Comparism of Women Representation in the 1999, 2003.2007 and 2011 Nigerian Elections

\begin{tabular}{|c|c|c|c|c|c|c|c|c|}
\hline & \multicolumn{2}{|c|}{1999} & \multicolumn{2}{c|}{$\mathbf{2 0 0 3}$} & \multicolumn{2}{c|}{$\mathbf{2 0 0 7}$} & \multicolumn{2}{c|}{2011} \\
\hline Office & $\begin{array}{c}\text { Seat } \\
\text { Available }\end{array}$ & Women & $\begin{array}{c}\text { Seat } \\
\text { Available }\end{array}$ & Women & $\begin{array}{c}\text { Seat } \\
\text { Available }\end{array}$ & Women & $\begin{array}{c}\text { Seat } \\
\text { Available }\end{array}$ & Women \\
\hline President & 1 & 0 & 1 & 0 & 1 & 0 & 1 & 0 \\
\hline Senate & 109 & $3(2.8 \%)$ & 109 & $4(3.7 \%)$ & 109 & $9(8.3 \%)$ & 109 & $7(6.4 \%)$ \\
\hline House of Reps. & 360 & $12(3.3 \%)$ & 360 & $21(5.8 \%)$ & 360 & $25(6.9 \%)$ & 360 & $26(7.2 \%)$ \\
\hline Governor & 36 & 0 & 36 & 0 & 36 & 0 & 36 & 0 \\
\hline $\begin{array}{c}\text { State House of } \\
\text { Assembly }\end{array}$ & 990 & $24(2.4 \%)$ & 990 & $40(3.9 \%)$ & 990 & $57(5.8 \%)$ & 990 & $68(6.9 \%)$ \\
\hline $\begin{array}{c}\text { State House of } \\
\text { Assembly } \\
\text { Committee }\end{array}$ & 829 & $18(2.2 \%)$ & 881 & $32(3.6 \%)$ & 887 & $52(5.9 \%)$ & 887 & - \\
\hline $\begin{array}{c}\text { Local Government } \\
\text { Area } \\
\text { Chairperson }\end{array}$ & 710 & $13(1.8 \%)$ & 774 & $15(1.9 \%)$ & 740 & $27(3.6 \%)$ & 740 & - \\
\hline \begin{tabular}{c} 
Councilors \\
\hline
\end{tabular} & 6368 & $69(1.1 \%)$ & 6368 & $\begin{array}{c}267 \\
(4.2 \%)\end{array}$ & 6368 & $\begin{array}{c}235 \\
(3.7 \%)\end{array}$ & 6368 & - \\
\hline
\end{tabular}

Source: Eyeh (2010); Irabor (2011) and Okoronkwo-Chukwu (2013)

Table 2. Trends of Women Deputy Governors in Nigeria Since 1999

\begin{tabular}{|c|c|}
\hline Election Year & No. of Women Deputy Governors \\
\hline 1999 & 1 \\
\hline 2003 & 2 \\
\hline 2007 & 6 \\
\hline 2011 & 1 \\
\hline
\end{tabular}


However, from 1999 -2011, there has been a drastic increase in women political participation in both elective and appointive positions particularly appointive. In spite of these increases, women are still highly marginalized considering the disparity in the proportion of men to women in politics and decision making positions (Ngara and Ayabam, 2013). Similarly, UNDP report concludes that women participation in politics and decision making is still inadequate (Asaju and Adagba, 2013).

Furthermore, despite these improvements, the representation of women in politics and decision making in Nigeria is still far below the global benchmark of $35 \%$ affirmative action. It is against this background that this paper examined "Challenges to women active participation in Politics in Nigeria".

\section{Conceptual Clarification}

\subsection{Politics}

Politic refers to the activities of the government members of lawmaking organization or people who try to influence the way a country like Nigeria is governed.

\subsection{Women}

Generally, the word 'women' means any adult female person as contrasted with girl. Women, from the Nigerian political arena, are adult female persons who have attained the age of franchise (18 years of minimum age).

\subsection{Active Participation}

Active participation here refers to active political participation which is seen as those voluntary activities by which members of the society share in the selection of leaders and directly or indirectly in the formation of policy and is a civic right of all citizens. Political participation involves essential political activities such as attending political meetings, rallies, campaigns, nominations, elections, etc; holding political party offices and public offices; contesting for elective positions; voting in elections; holding elective and appointive positions; attaining political power in legislative bodies; and other electoral activities.

\subsection{Indigenization}

Indigenization is where a married woman political aspirant is denied support in contesting for electoral position/seeking appointive position from her state of origin and that of her husband on the basis that having married outside her state she has lost her indigene ship and that she is a stranger in her husband's state of origin respectively. It simply refers to lack of constituency base for any married Nigerian women political aspirants.

\subsection{Challenges}

Challenges here refer to the factors that have been proved to stand on the way of Nigerian women thereby preventing them from active participation in politics of their country (Nigeria).

\section{Challenges to Women Active Participation in Politics in Nigeria}

The challenges to women active participation in politics in Nigeria are manifold. In this paper, some of these challenges examined include but are not limited to the following:

\subsection{Discriminatory Socio-cultural and Religious Practices}

The entrenched socio-cultural and religious practices in Nigeria skewed in favour of men and against women constitute serious challenge to women active participation in politics. Women (including Nigerian women), according to Muoghalu and Abrifor (2012), are discouraged from participating in public life from childhood through adulthood by authority figures such as husbands, fathers, mothers and other relations due to cultural image of a virtuous woman defined as quiet, submissive who should be seen and not heard. Because of the patriarchal nature of the Nigerian society, most Nigerians including women still believe and accept the traditional perspectives that view women as inferior to men, second class citizens, weaker sex, to be seen and not heard, child bearers/ primary care-givers, etc. In most cases, they feel the game of politics is an exclusive reserve of men and dare not venture into it and those who manage to venture are usually contented with the back seats (Ngara et al., 2013).

Likewise, religious practices are used as powerful instruments of stereotype against Nigerian women political aspirants/politicians from active participation in politics. For instance, in Northern Nigeria, the purdah system (i.e. house seclusion of women) of the Islamic doctrine strictly bars women from participating in politics either as voters, political aspirants or even participating in campaigns/other electoral activities. However, when it comes to the issue of political leadership and formulation of government policies women's role in Islam is limited to supportive and advisory (Nwankwo and Surma, 2008). Also, the Christian doctrine does not accord women much role in public life.

\subsection{Lack of Finance}

Politics in Nigeria, especially seeking elective position is an expensive venture requiring huge financial involvement and solid financial backing. Generally, the relatively pathetic poor financial disposition of Nigerian women is a critical challenge which mostly accounts for their poor participation in politics and political defeat in elections. About $90 \%$ of women in Nigeria, according to Ngara et al. (2013), currently live below poverty line, so in spite of concession granted by 
some major political parties which lowers the cost of obtaining party nomination forms for women into elective office, nonetheless, the cost of realizing electoral ambition is still far beyond the reach of even the most highly placed women in the absence of "a godfather who foots the bill in exchange for unlimited favour when the seat is eventually secured" (Yahaya, 2012). Considering the financial backing, the godfathers' and other financiers of politicians in Nigeria prefer male political aspirants to female ones based on the societal value assumption that political activities are masculine and male candidates are believed to stand better chance of wining elections. In Nigeria, the women poor access to credit facilities, lack of inheritance rights for developmental purposes; including culturally unacceptable control of their income and resources while living with their husbands (for married ones) contribute to their lack of financial strength as a major challenge in their active participation in politics.

\subsection{Under-representation of Women in Governance}

Nigerian women are marginalized, discriminated against and are greatly under-represented in politics and governance where important decisions are taken relative to their male-counterparts which is a terrible challenge to their active participation in the nation's politics. It is regrettable that although women constitute the greater number of the registered voters in any elections held in Nigeria, they are yet to experience full representative positions (Okoronkwo-Chukwu, 2013). The 1999 Nigeria Constitution generally refers to non-discrimination on the basis of sex, etc but is not explicit in ensuring equal representation on gender basis, takes no cognizance of the disadvantaged position of women, and has no provision for gender equality. Likewise, "the Federal Character Principle, which is meant to ensure equitable representation of states and ethnic groups in national appointments, actually places Nigerian women at additional disadvantage by implying that they can only represent their ethnic and states of origin. Where culture does not permit a woman to represent her place of birth, she loses a golden opportunity. There have been many cases where a woman's state of origin disallows her appointment and the husband's state also refuses to endorse her. In many of these instances the government plays safe by appointing a man instead. And this has continued to consolidate women's under-representation in national politics (Agbalajobi, 2010). Based on the quota allocation system as approved by the UN to be implemented in global politics, and the Beijing Conference agreement on $30 \%$ public seats and positions to be reserved for women, it is evident that there has been an increase in the number of Nigerian women in elective and appointive positions. Yet, there is still under-representation of Nigerian women in governance which is another major challenge to their active participation in politics.

\subsection{Unhealthy Political Environment}

Unhealthy Political environment is another challenge to women active participation in politics in Nigeria. The political terrain in Nigeria is do-or-die affair fraught with violence, maiming, assassinations, threats, blackmail, intimidation, humiliation, etc which are used by mostly men to scare women away from active participation in politics in Nigeria.

Involvement of thugs before, during and after elections (Kolawal et al., 2012), and the attendant insecurity such as destruction of lives and properties that characterized a typical electoral process in Nigeria makes politics something out-of-the-way for most women (Ngara et al., 2013). An illustration of electoral violence in Nigeria is the testimony of a female aspirant, Dorathy Nyone who narrated that "a ward chairman was shot dead; all the women and most of the men fled the scene. My husband rushed there and took me home. I was scared; men who were fully prepared for violence were the only ones who remained behind to hand pick the various winners" (Luka, 2011). Nigerian women have over the years become targets of violence of diverse forms based on their positions in promoting transformative politics (Agblajaobi, 2010).

\subsection{Political Party Discrimination}

In Nigeria, political party is the framework for the attainment of political ambitions by politicians. Its hierarchy, membership, and funding are still male-dominated which made it possible for them to be influencing the party's internal politics and often sideling women. The manifestos and constitutions of political parties in Nigeria rarely mention Affirmative Action for women, and when they do, their commitments are lower than the bench mark set by regional and International conventions. The political party discrimination against women in politics in Nigeria is often a deliberate effort to humiliate and frustrate them into losing focus and excluding them from active participation in politics. For instance, the timing of political meetings (mostly late in the night) and serious politicking which involves a lot of traveling automatically exclude mostly married women from active participation in politics. The governance structures in the political parties may play a critical role on who actually gets nominated to vie for elective positions. The Nigerian women are not likely to be voted into key positions in the political party hierarchy. The highest position held by women in a number of key political parties include most insignificant posts of ex-officio members and women leaders whose importance is only for mobilizing womenfolk to vote for men. Thus, they are usually unable to assert themselves or push for the interest of women during nominations leading to marginalization of women during election. In addition, most Nigerian political parties marginalize and discriminate against female political aspirants by excluding them from politics through traditional methods based on male-centred interpretation of culture, religion and sharp practices of "zone out" and "step-down techniques mainly for women. The "zone out" technique is 
where a political party simply zones out the seat of a female aspirant to constituency she is not regarded as an indigene while "step-down" technique is where a female candidate who has clearly scaled through party nomination and is eligible to contest an election is simply asked to step down for a more suitable candidate (mostly men).

An example of affirmative action by political parties is mainly waiving of the fees obtaining the party nomination forms for women into elective positions. Affirmative action in the form of special seats for women is one of the recommendations that would help address poor representation. However, it will not work in all cases. Provision of room for nominations of women after the elections is not yet applicable in Nigeria.

In most political parties in Nigeria, the discrimination against women from the men folk in selecting, electing or voting for candidates for elections and in allocating political offices which most often tend to relegate women to the background is a critical challenge to women active participation in politics.

\subsection{Wrong Perception of Women in Politics}

In Nigeria, women who are actively participating in politics are seen and treated as free women (prostitutes/wayward) of easy virtues, stubborn people, whores, too domineering, cultural rebellions, etc. It is observed that during campaign, the political opponents (mostly men) use the alleged loose moral standing of these women against them and often insult them directly in public. Thus, they are often subjected to public ridicule and are socially stigmatized by both men and women. The use of negative labeling; derogatory names; abusive language and expressions to describe Nigerian women in politics discourage many of them from active participation in the nation's politics.

\subsection{Lack of Family, Fellow Women and Media Supports}

Lack of family support is a critical challenge to women active participation in politics in Nigeria. Because of the patriarchal nature of Nigerian society, it is culturally assumed that women must seek permission from the $\mathrm{men} / \mathrm{husbands}$ before venturing into politics. However, if such permission is not granted, the only option for such women is to drop their political ambitions. Thus, most family members especially husbands even among the educated ones do not allow women wives to participate actively in politics in Nigeria. Many poor women political aspirants do not enjoy family support financially, socially, and otherwise.

The Nigerian women political aspirants/politicians lack support of their fellow women politically which is a major challenge to their active participation in politics. It is unfortunate that women in Nigeria do not have expected confidence in the leadership abilities of their fellow women and do not support them to win elections. Although, factors like envy, jealousy, and other problems associated with interpersonal relations are common with women, generally, most women would rather vote or support men to win election than their fellow women in spite of their numerical strength (Ngara et al., 2013) and such is applicable to Nigerian women. However, this has placed the Nigerian men at an advantage vis-avis their women counterparts when it come to mobilizing support for elections. In Nigeria, "a classical example of this scenario was the case of Mrs Sarah Jubril, who contested against the President Goodluck Jonathan and former Vice-President Atiku Abubakar in the Peoples Democratic Party presidential primaries preparatory to the 2011 general elections. At the end of the exercise, Sarah Jubril pulled only one vote -obviously an own vote. This shows that even her closes female supporters did note vote for her (Ngara et al., 2013). However, many Nigerian women psychologically regard and perceive the social stigma that politics is a "dirty game" and as such tend to wrongly perceive fellow women into politics as arrogant and irresponsible and want to pull them down. As a result of this syndrome, most Nigerian women dread politics to retain their good personality traits and not break their matrimonial home (for the married ones).

Another serious challenge to women active participation in politics in Nigeria is lack of media support. Most of the political feats of women in Nigerian cultural histories are not properly mentioned / documented or down-played to make them irrelevant to the national history and heritage mainly because of the patriarchal nature of nation. Unfortunately, most media houses refuse to project the female political aspirants. For instance, Hon. Barrister (Mrs.) Ugochi Nnanna- Okoro, politician and former Peoples Democratic Party governorship aspirant in Imo state in the 2003 general elections in Nigeria had ugly experiences with the media. Ugochi, according to Nwankwo (2005) "was shocked to find her access to state-owned Radio and Television Stations blocked. Money she paid for publicity was returned to her 'on the pretext that I failed to get approval from the Imo State Government, Also at the Imo Broadcasting service, some retorted, 'Madam take back your money. I don't want to be sacked' she said".

Most media publicly present stereotyped or negative images of Nigerian women political aspirants/politicians. They appear to disparage women roles and contributions to national development. There is always poor media coverage of women political campaign and other electoral activities thereby discriminating against them to probably favour their male counterparts.

\subsection{Indigenization of Women Political Aspirants}

The Constitution of the Federal Republic of Nigeria, according to Olufemi (2006) continues to act as an impediment to women's active political ambitions as married women is often confronted with the problem of constituency, especially if she is married outside her locality or state of origin as she cannot claim the state of origin of her husband. If a married Nigerian woman goes back to her constituency 
or birth/state of origin, she is likely to receive the same discriminatory treatment for she regarded as being over ambitious and a "non-indigene" by her own state of origin. Similarly, such women have no base from which to develop political contacts with the people or build knowledge and experience about the issues in the areas and are not considered for elective positions. Thus, the indigenization of Nigerian women that discourages them from active participation in politics is a remarkable challenge.

\section{Conclusions}

The global issue of goal 3 (to promote gender equality and empower women) of the Millennium Development Goals (MDGs) and other international clarion calls for bridging the gap created by long-term discriminations against women and making women visible in politics made Nigeria to recognize women in the political sphere, and include them in both appointive and elective positions. It is no doubt that women still remain highly marginalized, discriminated against; and are under-represented in political life of the nation. This is more obvious when the proportion of men to women in politics and decision making positions is compared despite the fact that women represent $50 \%$ of the nation's population. Several challenges that Nigerian women still face in active participation in politics such as discriminatory socio-cultural and religious practices; lack of finance; under-representation of women in governance; unhealthy political environment; political party discrimination; wrong perception of women in politics; lack of family, fellow women and media support; indigenization of women political aspirants; among others, have been identified as responsible for this state of affair. Thus, the recommended measures to guarantee women active participation in politics in Nigeria included review of discriminatory practices; economic empowerment; support from family, fellow women and media; equal representation in governance; healthy political environment; proper perception of women in politics, among others.

\section{Recommendation}

Based on the conclusion, the following recommendations are made.

\subsection{Review of Discriminatory Practices}

Discriminatory socio-cultural and religious practices against women active participation in politics in Nigeria should be positively reviewed by stakeholders (particularly traditional/religious rulers and government) who should be educated to be gender sensitive and encouraged to protect women political and other rights and ensure support of their political ambitions. These stakeholders should ensure that cultural/religious practices that discriminate against women are discouraged and their perpetuators are adequately punished to serve as deterrent measures.

\subsection{Economic Empowerment of Women}

Women should be given equal access to credit facilities and factors of production like land and labour just like men to enhance their output and income generation. The discriminatory laws of inheritance, succession and land tenure; and collateral of husband's consent for granting loans to women which deny them the legal ownership and possible access to credit facilities should be eliminated. In addition, government should adopt and strictly enforce deliberate policy frameworks and empowering programmes by all stakeholders.

\subsection{Support from Family, Fellow Women, and Media}

Family members (especially husbands of married women) should give women political aspirants the relevant consent and support to venture into politics and governance. Through awareness campaign and voters' education prorammes, women should be informed of their political rights to participate actively in politics not only as voters but also to be voted for in the numerous political positions and be encouraged to support and vote for their fellow women political aspirants/politicians. Furthermore, media should support Nigerian women political aspirants/politicians by publicly projecting their positive images; emphasizing their important roles and contributions to national development; raising their participation awareness in politics and governance; deploring discriminations against them; among others. The gender stereotypes in the media should be discouraged.

\subsection{Equal Representation in Governance}

There should be equal representation of Nigerian men and women in governance to ensure that enacting laws of the land and making policies particularly those affecting gender issues will always remain equitable. There should be enabling Constitutional amendment to ensure equitable appointive and elective positions in governance for meaningful national development. The national legislations should comply with International standards established in various international treaties and instruments for elimination of discrimination against women and to capture the interest of women through adequate representation. Political empowerment, especially through the strengthening of affirmative action and allocation of quota for Nigerian women in politics and decision making positions should be strictly implemented to encourage their active participation in politics.

\subsection{Proper Perception of Women in Politics}

The use of negative labeling, derogatory names, abusive language and expressions to describe women in politics 
should be discouraged through sensitization and public enlightenment campaigns in Nigeria The campaigns of male political opponents that portray Nigerian women as acting against the Nigerian culture of not accepting leadership roles of women just to marginalize them should be discouraged. In Nigeria, women in politics should be properly perceived as partners of their male counterparts in politics and governance of the nation.

\section{REFERENCES}

[1] Agbalajobi, D. T. (2010). "Women's Participation and the Political Process in Nigeria: Problems and Prospects." African Journal of Political Science and International Relations, 4 (2), 75-82.

[2] Asaju, K. \& Adagba, S. O. (2013). "Women Participation in National Development in Nigeria: Imperative of Education." Journal of Public Administration and Governance, 3 (1), 57-69.

[3] Eyeh, S. O. (2010). "From Myth to Consciousness: The Novel as Mimetic Mode of Women's Sociocultural and political transformation in Nigeria." Journal of the Nigeria English 1 Studies Association, 13(2), 137-150.

[4] Irabor, F. O. (2011). Review of Women's Participation and Performance at the 2011 General Elections in Nigeria. Baobwomen.org.

[5] Kolawale, T. O., Abubakar, M. B., Owonibi, E. \& Adebayo, A. A. (2012). "Gender and PartyPolitics in Africa with Reference to Nigeria." Journal of Education Research, 1(7), 132-144.
[6] Luka, R. C. (2011). "Women and Political Participation in Nigeria: The Imperatives of Empowerment." Journal of Social Sciences and Public Policy, 3, 24-37.

[7] Muoghalu, C. O., \& Abrifor, C. A. (2012). "Urban Poor Women and Governance in Nigeria." European Scientific Journal, 8(5), 176-185.

[8] Ngara, C. O., \& Ayabam, A.T. (2013). Women in politics and decision- making in Nigeria: chanllenges and prospects. European Jonrnal of Business and Social Sciences, 2(8), 47-58.

[9] Nwankwo, O. (2005). Gender inequality and political proceeding of a national tribunal on the violation of political rights of women in Nigeria. Enugu, Nigeria: Fourth Dimension Publishing Co., LTD

[10] Nwankwo, O., \& Surma, N. (2008). Affirmative Action for Women in Politics: from projects to policy change. Nigeria: Civil Resource Development and Documentation Centre

[11] Ogunyankin, G. A. (2012). The Gendering of Politics in Nigeria- Part 1 http://www.makeeverywom ancount.org/index.php?

[12] Okoronkwo-Chukwu, U. (2013). "Female Representation in Nigeria: The Case of 2011 General Elections and the Fallacy of 35\% Affirmative Action." Research on Humanities and Social Sciences, 3(2), 39-46.

[13] Olufemi, O. (2006). Democracy and development. Lagos: Joja Educational Research and Publishers. Ltd.

[14] The 1999 Constitution of the Federal Republic of Nigeria.

[15] Yahaya, A. (2012). "Muslim Women and Political Participation in Nigeria" Paper Presented at the Nigerian Muslim and Democracy Conference Abuja. 